\title{
Pengembangan Hukum Wakaf Produktif Untuk Mengatasi Kemiskinan Dan Ketergantungan
}

\author{
Aunur Rohim Faqih
}

\begin{abstract}
Abstrak
To develop the economics of the society and to minimize poverty and interdependence, the management of property donated for religious use (wakaf) productive can be exercised by modern management and it is managed by the professional people, trusted, productive and constantly based on the Islamic values and the related regulations.
\end{abstract}

\section{Pendahuluan.}

Sistem ekonomi kapitalis merupakan salah satu penyebab munculnya masalah perekonomian yang cukup pelik bagi negara berkembang. Di samping struktur ekonominya, kemiskinan, keterbelakangan pendidikan, rendahnya kualitas sumber daya manusia dan masalah-rnasalah lain menjadikan negara berkembang tersebut semakin bertambah berat beban permasalahannya. Indonesia sebagai negara berkembang juga mengalami hal serupa. Bahkan akhir-akhir ini permasalahan sosial ekonomi di Indonesia semakin bertambah rumit dengan adanya berbagai peristiwa alam, mulai dari banjir di beberapa daerah, kelangkaan bahan bakar minyak dan gempa bumi, gempa tsunami di Aceh dan Sumatera Utara, busung lapar dan wabah flu burung diberbagai daerah.

Upaya untuk mencari jalan keluar dalam mengatasi berbagai masalah khususnya kemiskinan dan ketergantungan karena dampak krisis ekonomi yang terjadi pada tahun
1997, masih terus dilakukan dan belum terbukti adanya titik terang alternatif yang tepat. Berbagai kebijakan sudah dilakukakan oleh pemerintah, namun hasilnya belum begitu menggembirakan, bahkan kemiskinan masih melanda penduduk di berbagai daerah. Yang sangat menyedihkan lagi kebijakan pemerintah untuk mengatasi masalah ekonomi cenderung membuat negara kita bergantung kepada negara-negara lain.

Sebagai Negara yang penduduknya mayoritas beragama Islam, adalah merupakan keharusan bagi 'alim-ulama dan kaum intelektual muslimnya mencari strategi lain untuk mengatasi kemiskinan dan ketergantungan ekonomi kepada negara-negara lain. Dalam hal ini ada pemikiran dari sebagian 'ulama dan kaum intelektual muslim untuk secara perlahan dan bertahap menerapkan sistem ekonomi Islam sebagai alternatif dari sistem ekonomi yang ada sekarang ini. Dengan diterapkannya sistem ekonomi Islam tersebut, diharapkan berbagai permasalahan ekonomi secara 
bertahap dapat di atasi. Dalam kesempatan ini perlu dikaji secara mendalam tentang pengembangan wakaf produktif untuk mengatasi kemiskinan dan ketergantungan.

\section{Islam dan Ekonomi Ummat}

Islam menuturkan bahwa setiap manusia sama derajatnya dihadapan Allah oleh karena itu umat manusia dipandang sebagai satu keluarga. Untuk merealisasikan kekeluargan dan kebersaman tersebut, harus ada kerja sama secara sukarela ('antaradhin-minkum') dan tolong menolong secara benar (ta'awanu 'alal birri wa taqwa'). Konsep persaudaraan dan perlakuan yang sama terhadap seluruh anggota masyarakat di muka bumi tidaklah mempunyai arti kalau tidak disertai dengan keadilan ekonomi yang memungkinkan setiap orang memperoleh hak atas sumbangannya terhadap masyarakat. Dengan komitmen Islam yang khas dan mendalam terhadap persaudaraan, keadilan sosial dan ekonomi, maka ketidakadilan dalam pendapatan dan kekayaan yang berlangsung saat ini adalah bertentangan dengan Isiam. Akan tetapi konsep keadilan Islam dalam distribusi pendapatan dan kekayaan serta konsepsinya tentang keadilan sosial tidaklah menuntut bahwa semua orang harus mendapat upah yang sama tanpa memandang konstribusinya kepada masyarakat. Islam memberikan toleransi ketidaksamaan pendapatan sampai tingkat tertentu, karena setiap orang tidaklah sama sifat, kemampuan dan pelayanannya dalam masyarakat ${ }^{3}$. Adanya perpedaan derajat kemampuan serta perbedaan dalam kesempatan dapat menjadi sebab musabab dari perbedaan dalam perolehan rezeki yang mungkin diterima oleh seseorang. Akibat lebih lanjut adalah lahirnya golongan kaya (qaum aghniaa) dan golongan miskin (qaum duafa'Masakin) dalam masyarakat, jurang pemisah yang semakin dalam antara keduanya. Dalam al-Quran terdapat petunjuk dan pedoman bagi seseorang untuk membelanjakan hartanya, baik untuk kepentingan dirinya sendiri maupun untuk kepentingan orang lain dalam masyarakat. Petunjuk itu antara lain terdapat dalam surat al - Isra' ayat 26 : "Dan berikanlah bagi keluarga - keluarga yang dekat akan haknya, kepada orang miskin dan orang yang dalam perjalanan; dan janganlah kamu menghambur - hamburkan (hartamu) secara boros". Dan "bahkan mengeluarkan sedekah kepada orang yang membutuhkaan berakibat pada kebersihan dan kesucian diri". ${ }^{4}$

Dari uraian tersebut nampak jelas bahwa perekonomian dalam Islam sangat peduli terhadap kaum yang lemah di satu sisi, dan sekaligus mendorong umat untuk bekerja

1 An-nisa (4):29: Hai orang-orang yang beriman, janganlah kamu saling memakan harta sesamamu dengan jalan yang batil, kecuali dengan jalan perniagan yang berlaku dengan sukarela diantara kamu( 'antaradhin minkum). Dan janganlah kamu membunuh dirimu, sesungguhnya Allah Maha Penyayang kepadamu.

${ }^{2}$ Al- Maidah (5):2: “......... dan tolong- menolonglah kamu dalam(mengerjakan) kebajikan dan taqwa, dan jangangan tolong-menolong dalam berbuat dosa dan pelanggaran"

${ }^{3}$ An Naahl ayat 71: "Dan Allah melebihkan sebagian kamu dari sebagian yang lain dalam hal rezeki......."

${ }^{4}$ S. At-Taubah ayat 103: "Ambillah sedekah dari sebagian harta mereka, dengan sedekah itu kamu bersihkan dan sucikan mereka", dan Hadis Nabi riwayat al-Bukhari dan Muslim dari lbnu Abbas: "Beritahukanlah kepada mereka, bahwa Allah mewajibkan atas mereka yang diambil dari orang-orang kaya, kemudian dikembalikan kepada orang-orang fakir". 
keras. Menurut Monzer Kahf setiap kegiatan ekonomi dalam Islam harus didasarkan pada asas filsafat ekonomi Islam. Adapun asas filsafat ekonomi islam adalah: (1) Semua yang ada di alam semesta, langit, bumi serta sumber alam yang ada padanya, bahkan harta kekayaan yang dimiliki manusia adalah milik Allah. Manusia sebagai khalifah-Nya hanya berhak mengurus dan memanfaatkan alam semesta itu untuk kelangsungan hidup manusia itu sendiri dan lingkungannya; (2) Allah Maha Esa, yang menciptakan segala makhluk yang ada di alam semesta ini. Manusia sebagai makhluk Allah diberi alat kelengkapan yang paling sempurna dibanding makhluk lain, agar ia mampu melaksanakan tugas, hak dan kewajibannya sebagai khalifah Allah di bumi itu, manusia yang berasal dari substansi yang sama, wajib saling bantu membantu dan bekerjasama terutama dalam melakukan kegiatan ekonomi untuk memenuhi keperluannya berdasarkan persamaan dan persaudaraan; (3) Beriman kepada hari kiamat. Keyakinan kepada hari kiamat ini sangat penting dalam sistem ekonomi Islam karena dengan keyakinan itu, tingkah laku ekonomi manusia di dunia ini akan dapat terkendali, sebab ia sadar bahwa semua perbuatan, termasuk tindakan ekonominya akan dimintai pertanggungjawabnya di hadapan Allah'5.

Berangkat dari asas pokok filsafat ekonomi Islam tersebut di atas, dapat melahirkan nilai-nilai dasar sistem ekonomi Islam seperti yang diungkapkan oleh Muhammad Daud Ali. Adapun nilai-nilai dasar sistem ekonomi Islam itu adalah:

1. Nilai dasar pemilikan. Menurut sistem ekonomi Islam, pemilikan bukanlah penguasaan mutlak atas sumber-sumber ekonomi, tetapi kemampuan untuk memanfatkannya, dan lama pemilikan manusia atas sesuatu benda terbatas pada lamanya manusia itu hidup di dunia ini, dan sumber-sumber daya alam yang menjadi hajat hidup orang banyak harus menjadi milik umum atau Negara.

2. Nilai keseimbangan. Nilai keseimbangan merupakan nilai dasar yang mempengaruhi berbagai aspek tingkah laku ekonomi seorang muslim. Asas keseimbangan ini misalnya terwujud dalam kesederhanaan, hemat dan menjauhi keborosan. Nilai dasar keseimbangan ini harus dijaga sebaik-baiknya bukan saja antara kepentingan dunia dengan akhirat dalam ekonomi, tetapi juga keseimbangan antara kepentingan perorangan dengan kepentingan umum, serta keseimbangan antara hak dengan kewajiban ${ }^{6}$.

Hubungan manusia dengan benda dan kekuasaan manusia atas segala sesuatu yang berada di sekitarnya adalah menjadi masalah penting dalam sistem ekonomi Islam, oleh karena itu perlu selalu dikontrol dan dikawal penegakannya. Mengenai hubungan manusia dengan benda atau hak milik seseorang atas. harta kekayaannya, perlu diperhatikan hal-hal berikut:

1. Cara memperoleh hak milik.

Mengenai cara memperoleh hak milik atau harta kekayaan, al-Qur'an memberikan beberapa ketentuan, diantaranya dengan (a) usaha yang halal, artinya sah menurut hukum dan benar menurut

${ }^{5}$ Ahmad M Saifuddin, Studi Nilai-nilai Sistem Ekonomi Islam (Jakarta: Media Dakwah, 1984), hlm. 19

${ }^{6}$ Mohammad Daud Ali, Sistem Ekonomi Islam, Zakat dan Wakaf, (Jakarta: UI Press, 1988). Hlm.7-8 
ukuran moral (Q.S. 2: 166, 4:32), (b) melalui pewarisan (Q.S. 4: 7), (c) dengan hibah (Q.S. 2: 177).

2. Fungsi hak milik.

Mengenai fungsi hak milik seseorang, alQur'an memberikan beberapa petunjuk, antara lain adalah (a) harta kekayaan seseorang tidak boleh ditimbun-timbun saja tanpa ada manfaatnya bagi orang lain (Q.s. 9:34); (b) harta kekayaan tidak boleh hanya beredar di antara orang-orang kaya saja; (c) Di antara harta orang kaya ada hak orang miskin yang tidak punya (Q.S. 51:19); (d) harta peninggalan seseorang harus segera dibagi kepada yang berhak menerimanya menurut ketentuan yang berlaku (Q.s. 4:7, 11, 12).

3. Cara memanfaatkan hak milik.

Tentang cara memanfaatkan atau mempergunakan harta kekayaan yang dimiliki seseorang, al-Quran memberikan beberapa pedoman, antara lain (a) tidak boleh boros dan tidak boleh pula kikir (Q.s. 17:26-27); (b) harus hati-hati dan bijaksana, selalu mempergunakan akal sehat dalam memanfaatkan harta (Q.S. 17:29); (c) sebaiknya disalurkan melalui hibah, qurban, zakat dan wakaf.

Kesenjangan antara orang kaya (qaum aghnia) dan orang miskin (qaum duafa) akan terkurangi. Apabila umat Islam menjalankan roda perekonomian berdasarkan filsafat ekonomi Islam dan nilai-nilai dasar sistem ekonomi Islam serta berdasarkan aturanaturan yang telah di tetapkan baik dalam al qur'an maupun dalam al hadist, dan ijtihad, serta teladan yang telah diberikan oleh para sahabat dan tabi'in. Cukup banyak lembagalembaga ekonomi Islam maupun lembaga kerjasama ekonomi yang dapat memberikan jaminan sosial, namun demikian lembagalembaga ekonomi tersebut tidak dapat berjalan dengan baik tanpa adaya peranan dari pelaku ekonomi dan dukungan riil dari pemerintah, antara lain berupa peraturan perundangundangan yang dapat memberikan perlindungan hukum bagi pengembangan ekonomi Islam. Salah satu lembaga ekonomi Islam yang pada saat ini perlu dikembangkan, selain zakat, infaq, perbankan syari'ah, asuransi syari'ah, reksadana syari'ah dan wakaf tunai.

\section{Hukum Wakaf Tunai}

Wakaf atau "habs" adalah salah satu lembaga yang sangat dianjurkan dalam Islam untuk dipergunakan sebagai sarana penyaluran rezeki yang diberikan oleh Allah kepadanya. Ayat-ayat al-Qur'an dan hadishadis Nabi yang memerintahkan orang untuk berbuat kebaikan kepada sesama manusia di masyarakat cukup banyak dan bisa dijadikan dasar umum amalan wakaf, dan sekaligus digunakan sebagai dasar hukum disyariatkannya wakaf. Sebagai contoh misalnya firman Allah yang artinya lebih kurang sebagai berikut " Hai orang orang yang beriman, nafkahkanlah (di jalan Allah) sebagian yang baik-baik dari hasil usahamu dan dari apa yang Kami keluarkan dari bumi untuk kamu. Dan janganlah kamu memilih yang buruk-buruk di antaranya yang kamu nafkahkan ... " Dan "Kamu tidak akan memperoleh kebaikan, kecuali kamu belanjakan sebagian harta yang kamu senangi" 8

\footnotetext{
7Mohammad Daud Ali, Ibid., Hlm.21-23

${ }^{8}$ S. Al-Hajj ayat 77, S. Al-Baqarah ayat 267 dan S. Ali 'Imran 92.
} 
Sedangkan hadist yang dijadikan landasan khusus untuk mewakafkan harta yang dimiliki seseorang adalah hadist yang diriwayatkan oleh Jama'ah dari lbnu Umaryang menyebutkan bahwa Umar bin Khatab pernah mendapatkan sebidang tanah di khaibar, kemudian merundingkan tanah tersebut dengan Rasulullah; Ya Rasulullah, sesungguhnya saya mempunyai tanah di Khaibar, saya belum pernah mendapatkan harta yang lebih saya senangi selain tanah itu, ia adalah yang termahal pada saya. Kini apa yang engkau sarankan kepada saya? Kemudian Rasulullah menjawab; " in syi'ta habasta ashlaha wa tashaddaq biha (Jika engkau mau, tahanlah pangkalnya dan sedekahkan hasilnya). Dengan demikian Umar menyedekahkannya, dengan syarat tidak boleh dijual, tidak boleh dihibahkan dan tidak boleh diwariskan. Adapun hasilnya itu disedekahkan untuk orang-orang fakir dan keluarga dekat, untuk memerdekakan hamba sahaya, untuk menjamu tamu; untuk orang yang kehabisan bekal dalam perjalanan (ibnussabii) dan tidak berdosa yang mengurusinya itu untuk memakan sebagian dengan cara yang wajar dan untuk memberi makan kepada keiuarganya dengan syarat jangan dijadikan hak milik. Dalam satu riwayat disebutkan bahwa harta yang diwakafkan tersebut tidak boleh dikuasai pokoknya9 .

Memperhatikan perjalanan sejarah kebangkitan Islam terbukti bahwa wakaf telah mempunyai peran sangat penting dalam pengembangan kegiatan-kegiatan sosial ekonomi dan kebudayaan masyarakat Islam dan telah menfasilitasi sarana dan prasarana pendidikan dari tingkat dasar sampai perguruan tinggi, bahkan para siswa dan mahasiswa sekaligus pendidik, mereka dapat melakukan berbagai kegiatan seperti penelitian dan menyelesaikan studi. Cukup banyak program-program yang didanai dari hasil wakaf seperti tempat-tempat pendidikan, pondok pesantren, kegiatan-kegiatan ilmiah dalam berbagai bidang, penulisan buku, dan lain-lain. Disamping untuk mendukung pengembangan iimu pengetahuan, tetapi juga menyediakan berbagai fasilitas untuk kepentingan ummat, seperti pengadaan fasilitas-fasilitas untuk meningkatan kesehatan masyarakat dengan pembangunan rumah sakit, dan pembangunan industri obat-obatan Dilihat dari segi bentuknya wakaf juga tidak terbatas pada benda tidak bergerak,tetapi juga benda bergerak. Di beberapa negara seperti Mesir, Yordania, Saudi Arabia, Turki wakaf selain berupa sarana dan prasarana ibadah dan pendidikan juga berupa tanah pertanian, perkebunan, flat, uang, saham, real estate dan lain-lain yang semuanya dikelola secara produktif. Dengan demikian hasilnya benarbenar dapat dipergunakan untuk meningkatkan kualitas umat dan mewujudkan kesejahteraan umat.

Akhir-akhir ini upaya untuk mengembangkan potensi wakaf khususnya wakaf produktif terus menerus dilakukan melalui berbagai pengkajian, agar di masa mendatang mempunyai peranan dalam pembangunan ekonomi umat. Cukup banyak pemikir-pemikir Islam khususnya pakar hukum Islam dan ekonomi Islam di dunia ini yang mengkaji secara sungguh-sungguh tentang wakaf, sebagai contoh misalnya, Monzer Kahf, Khaled

9Saayid Sabiq, Fikih Sunnah, Jilid 14, diterjemaahkan oleh Drs. H. Kahaar Mashur, (Jakarta, Kalam Mulia, 1991), hlm. 192 
R. Al-Hajeri dan Abdulkader Thomas, M.A. Mannan dan lain-lain. Pengkajian tentang wakaf ini tidak hanya terjadi di universitas-universitas Islam, tetapi juga di Harvard University. Di Universitas ini para pakar ekonomi syari'ah berkumpul untuk mengkaji masalah ekonomi Islam termasuk di dalamnya mengenai wakaf. Hal ini semakin meyakinkan kita bahwa wakaf merupakan salah satu lembaga sosial ekonomi Islam yang potensial untuk dikembangkan.

M.A. Mannan yang telah berhasil mengembangkan sertifikat wakaf tunai di Bangladesh mengemukakan bahwa banyak sasaran yang bisa dicapai dengan wakaf tunai. Menurutnya perbankan bisa menjadi fasilitator untuk menciptakan wakaf tunai dan membantu dalam pengelolaan wakaf. Di samping itu mobilisasi tabungan masyarakat bisa dilakukan dengan menciptakan wakaf tunai dengan maksud untuk memperingati orang tua yang telah meninggal, anak-anak dan mempererat hubungan keluarga. wakat tunai juga bisa meningkatkan infestasi sosial dan mentransforma-sikan tabungan masyarakat menjadi modal, serta membatu pengembangan social capital market. Adiwarman Karim dari Karim Consulting menjelaskan bahwa di negaranegara maju wakaf ini dikenal dengan derma, ternyata mempunyai peran yang besar dalam membentuk GDP suatu negara. Dalam sepuluh tahun terakhir ( 1990-1999) di Amerika sektor derma mencapai 6,8 persen dari GDP dengan total penerimaan 315.9 miliar dolar $\mathrm{AS}^{10}$.

Besarnya dorongan untuk pengembangan wakaf produktif tersebut tentu tidak dibenarkan kalau tidak berlandaskan pada ketentuan- ketentuan syariat Islam, karena wakaf merupakan ibadah. Oleh karena itu, setiap pembentukan wakaf perlu memperhatikan rukun dan syarat-sahnya. Menurut 'Abdul Wahhab Khallaf, rukun wakaf ada empat: (1) Orang yang berwakaf atau wakif, yakni pemilik harta benda yang melakukan perbuatan hukum; (2) Harta yang diwakafkan atau mauquf bih sebagai obyek perbuatan hukum; (3) Tujuan wakaf atau yang berhak menerima, yang disebut mauquf 'alaih; dan (4) Pernyataan wakaf dari wakif yang disebut syghat atau ikrar wakaf.

Mauquf bih atau harta yang diwakafkan merupakan salah satu rukun yang sangat relevan dikaji untuk mengetahui status hukumnya yang jelas dalam rangka memberikan jawaban kònkrit terhadap pengembangan wakaf itu sendiri. Namun demikian harta yang diwakafkan tersebut baru sah sebagai harta wakaf, kalau benda tersebut memenuhi syarat. Adapun syarat-syarat itu antara lain adalah sebagai berikut:

a. Harta yang diwakafkan itu harus benarbenar kepunyaan wakif secara sempurna, artinya bebas dari segala beban."

b. Benda yang diwakafkan harus kekal. Pada umumnya para ulama berpendapat bahwa benda yang diwakafkan zatnya harus kekal. Ulama Hanafiyyah mensyaratkan bahwa harta yang diwakafkan itu zatnya harus kekal dan memungkinkan dapat dimanfaatkan terus menerus. Mereka berpendapat bahwa pada dasarnya benda yang dapat diwakafkan adalah benda tidak bergerak (roerende goederen) bukan benda bergerak (onroerende goederen).

${ }^{10}$ Republika, 17 Mei 2004

"Muhammad 'Ubaid al-Kubaisyi, Al Ahkam al Waqf fi Syari'at al-Islamiyyah, Baghdad, Matba'ah AlInsyad, 1977, him. 351. 
Akan tetapi menurut Ulama Hanafiyyah benda bergerak dapat diwakafkan dalam beberapa hal: Pertama, keadaan harta bergerak itu mengikuti benda tidak bergerak dan ini ada dua macam: (a) Barang tersebut mempunyai hubungan dengan sifat diam di tempat dan tetap, misalnya bangunan dan pohon. Menurut Ulama Hanafiyyah bangunan dan pohon termasuk benda bergerak yang bergantung pada benda tidak bergerak. (b) Benda bergerak yang dipergunakan untuk membantu benda tidak bergerak seperti alat untuk membajak, kerbau yang dipergunakan bekerja dan lain-lain. Kedua, kebolehan wakaf benda bergerak itu berdasarkan ajaran yang membolehkan wakaf senjata dan binatang-binatang yang dipergunakan untuk berperang. Sebagaimana diriwayatkan bahwa Khalid bin Walid pernah mewakafkan senjatanya untuk berperang di jalan Allah ta'ala. Ketiga, wakaf benda bergerak itu mendatangkan pengetahuan seperti wakaf kitab-kitab dan mushaf. Menurut Ulama Hanafiyyah, pengetahuan adalah sumber pemahaman dan tidak bertentangan dengan nas. Mereka menyatakan bahwa untuk mengganti benda wakaf yang dikhawatirkan tidak kekal adalah memungkinkan kekalnya manfaat. Menurut mereka mewakafkan buku-buku dan mushaf yang tentunya dapat diambil pengetahuannya, hal ini sama dengan mewakafkan dirham dan dinar. Oleh karena itu Ulama Hanafiyyah membolehkan wakaf uang.

Ulama Hanafiyyah juga memperbolehkan mewakafkan barang-barang yang memang sudah biasa dilakukan pada masa lalu seperti tempat memanaskan air, sekop, kampak sebagai alat manusia bekerja.

c. Benda yang diwakafkan harus jelas wujudnya dan pasti batas-batasnya. Syarat ini dimaksudkan untuk menghindari perselisihan dan permasalahan yang mungkin terjadi di kemudian hari setelah harta tersebut diwakafkan. Dengan kata lain persyaratan ini bertujuan untuk menjamin kepastian hukum dan kepastian hak bagi mustahik untuk memanfaatkan benda tersebut ${ }^{12}$.

d. Benda yang diwakafkan harus bernilai ekonomis, tetap zatnya dan boleh dimanfaatkan menurut ajaran Islam dalam kondisi apapun. Namun, dalam Qanun yang ada di Mesir wakaf benda yang diwakafkan tidak hanya dibatasi pada benda-benda tidak bergerak, tetapi juga benda-benda bergerak ${ }^{13}$.

Dari beberapa pendapat yang sudah dikemukakan jelas bahwa pada prinsipnya para ulama termasuk ulama Hanafiyyah berpendapat bahwa syarat benda yang diwakafkan adalah benda-benda tidak bergerak, hanyabenda-bendabergerak tertentu saja yang boleh diwakafkan, yakni benda-benda yang memenuhi syarat yang sudah dikemukakan dan jenis-jenis benda yang sudah pernah diwakafkan oleh para sahabat.

Selain ulama Hanafiyyah, Imam az-Zuhri juga berpendapat bahwa mewakafkan dinar, hukumnya boleh dengan cara menjadikan dinar tersebut sebagai modal usaha. Keuntungan dari usaha tersebut kemudian disalurkan kepada mauquf 'alaih. Di samping Imam az-Zuhri dan Ulama Hanafiyyah,

\footnotetext{
${ }^{12}$ Wahbah az-Zuhaily: Fiqh Al-Islamy wa-Adillatuhu Dar al-Fikkri, Juz VIIl, HIm.185.

${ }^{13} \mathrm{lbid} .{ }^{20}$ Ahmad Azhar Basyir. Op. Cit. Hlm. 21
} 
sebagian Ulama Mazhab Syafi'i juga membolehkan wakaf dinar dan dirham. Bolehnya mewakafkan benda-benda bergerak seperti uang dan saham ini sangat penting untuk mengembangkan benda-benda tidak bergerak. Untuk itu perumusan tentang benda yang boleh diwakafkan sangat diperlukan, terutama di negara yang wakafnya belum berkembang dengan baik seperti Indonesia. Hasil penumusan tersebut harus disosialisasikan kepada umat Islam, sehingga umat Islam memahami masalah perwakafan dengan baik dan benar. Dengan demikian umat Islam dapat mengembangkan wakaf yang ada secara produktif dan hasilnya dapat dipergunakan untuk mewujudkan kesejahteraan sosial.

Komisi Fatwa Majelis Ulama Indonesia pada tanggal 11 Mei 2002 telah menetapkan bahwa wakaf uang dibolehkan. Adapun isi fatwa tersebut sebagai berikut:

1. Wakaf uang (Cash Wakat/Waqf al-Nuqud) adalah wakaf yang dilakukan seseorang, kelompok orang, lembaga atau badan hukum dalam bentuk uang tunai.

2. Termasuk ke dalam pengertian uang adalah surat-surat berharga.

3. Wakaf uang hukumnya jawaz (boleh).

4. Wakaf uang hanya boleh disalurkan dan digunakan untuk hal-hal yang dibolehkan secara syar'i.

5. Nilai pokok wakaf uang harus dijamin kelestariannya, tidakboleh dijual, dihibahkan, dan atau diwariskan. Wakaf uang ini penting sekali untuk dikembangkan di Indonesia untuk meningkatkan ekonomi kaum dlu'afa.

\section{Perkembangan Wakaf Tunai}

Dalam sejarah Islam, wakaf yang pertama kali dilaksanakan adalah wakaf
Masjid Quba' di Madinah. Masjid yang dibangun ketika Nabi Muhammad saw hijrah ke Madinah pada tahun $622 \mathrm{M}$. Tempat ibadah ini masih berdiri hingga hari ini pada tempat yang sama, meskipun telah mengalami beberapa kali perluasan dan perbaikan. Wakaf untuk tempat ibadah ini kemudian disusul dengan wakaf-wakaf mesjid di berbagai negara termasuk Indonesoia. Wakaf ini bersifat khusus karena untuk kepentingan tempat ibadah khusus.

Sedangkan wakaf yang bersifat umum merupakan jenis wakaf yang kedua. Wakaf jenis ini ditujukan untuk mendukung kepentingan umum yang lebih luas dan menyeluruh cakupan pemanfataannya, dan mampu mendanai lembaga dan kegiatan tertentu seperti perpustakaan, penelitian ilmiah, pendidikan, layanan kesehatan, pemeliharaan lingkungan. Hasil pengembangan wakaf pada saat itu juga dipergunakan untuk membantu modal bagi para pedagang kecil, pemeliharaan taman, jalan dan bendungan. Wakaf jenis ini pernah terjadi pada masa Nabi Muhammad saw, di mana pada saat itu ada seseorang bernama Mukhayriq mencantumkan dalam wasiatnya bahwa jika ia meninggal dunia nanti, tujuh lahan kebunnya akan diberikan kepada Rasulullah. Pada tahun $626 \mathrm{M}$, Mukhayriq meninggal dunia dan Nabi menerima kebun tersebut dan menetapkannya sebagai wakaf yang hasilnya untuk kepentingan fakir miskin. Praktik ini kemudian diikuti oleh para sahabat dan para pengikutnya, antara lain adalah Umar bin Khattab. Setelah Nabi Muhammad saw wafat pada tahun 632 , cukup banyak umat Islam yang mempraktikkan wakaf. Dalam perkembangannya, wakaf selain untuk kegiatan ibadah khusus keagamaan dan wakaf kepentingan umum (waqaf khaim), juga ada wakaf untuk keluarga 
(waqaf ahli).

Mesir merupakan negara yang selalu mengembangkan wakaf. Wakaf yang pertamatama terjadi di Mesir adalah wakaf Masjid Amr bin Ash yang juga merupakan mesjid pertama di Mesir. Mesjid ini wakaf dari Qaisabah bin Kaltsum at-Tahbibi pada tahun 21 Hijriyyah atau tahun $641 \mathrm{M}$. Perbuatan mewakafkan harta tersebut kemudian diikuti oleh kaum muslimin yang lain seperti Ummu Abdillah binti Musallamah bin Mukhad al-Anshari, dan lainlain. Benda yang diwakafkanpun semakin beragam, yang semula hanya mesjid kemudian gedung, tanah pertanian, kebun dan bendabenda lain yang diperlukan masyarakat.

Begitu banyaknya jumlah harta wakaf, maka diperlukan perangkat peraturan perundang-undangan yang mengatur manajemen khusus untuk mengelolanya, baik dalam memelihara dan mengembangkannya maupun dalam mengalokasikan hasil wakaf kepada mauquf 'alaih. Sejarah perkembangan pengelolaan harta wakaf di Mesir dimulai oleh seorang qadhi Mesir di masa pemerintahan Hisyam bin Abdul Malik, yakni Taubah bin Numair. Sebelumnya wakaf sering dikuasai keluarga wakif atau nadzir, namun setelah Taubah berkuasa, ia mengembalikan hasil wakaf kepada mauquf 'alaihnya. Dan untuk melakukan pengawasan terhadap harta wakaf, ia membentuk Dewan wakaf. Di antara harta wakaf yang sangat besar dan cukup dikenal di dunia Islam adalah Mesjid dan Universitas Al-Azhar. Mesjid dan Universitas ini dibangun pada masa Khilafah Fathimiyyah. Tradisi ini kemudian juga diikuti oleh masyarakat dan para Sultan, misalnya Sultan Qaitbay. la pernah mewakafkan sejumlah bangunan, berupa gudang, aula, asrama perkampungan Turki, pabrik dan tanah pertanian.
Dalam kenyataannya wakaf benda tidak bergerak tidak cukup untuk mengembangkan wakaf secara optimal. Untuk itu nampaknya perlu dikembangkan wakaf benda bergerak khususnya uang untuk mendukung pengembangan wakaf benda tidak bergerak.

Dalam sejarahpun, wakaf tidak terbatas pada benda tidak bergerak tetapi juga benda bergerak termasuk uang. Wakaf uang sebenarnya sudah dikenal oleh para ulama klasik. Memang mengenai masalah wakaf uang ada perbedaan pendapat di antara para ulama. Inti permasalahan sebenarnya ada pada pemahaman bahwa barang yang diwakafkan itu harus kekal atau tidak boleh rusak. Ulama yang membolehkan wakaf uang berpendapat, bahwa uang dapat diwakafkan asalkan uang tersebut diinvestasikan dalam usaha bagi hasil (mudlarabah), kemudian keuntungannya disalurkan sesuai dengan tujuan wakaf. Dengan demikian uang yang diwakafkan tetap, sedangkan yang disampaikan kepada mauquf 'alaih adalah hasill pengembangan wakaf uang itu. Pada saat ini sudah cukup banyak bermunculan bentuk baru pengelolaan wakaf uang. Munculnya bentukbentuk pengelolaan wakaf uang tersebut tidak terlepas dari munculnya berbagai bentuk investasi dan berbagai cara dalam pengelolaan ekonomi. Salah satu bentuk baru dalam pengelolaan wakaf uang adalah wakaf uang yang dikelola oleh perusahaan investasi. Biasanya wakaf uang di sini dikelola atas asas mudlarabah. Dalam hal ini uang diserahkan kepada badan atau yayasan yang menerima pinjaman usaha bagi hasil atau kepada yayasan yang dikelola oleh pengelola sewaan, sedangkan hasilnya diberikan kepada mauquf 'alaih sebagai amal kebaikan sesuai dengan tujuan wakaf. 
Wakaf investasi yang sekarang berkembang disamping kebutuhan juga merupakan hasil rekomendasi muktamar Menteri Wakaf seluruh dunia Islam pada tahun 1998. yang sangat mendorong perlunya wakaf investasi. Ada tiga lembaga yang menjadi stakeholder dalam wakaf investasi, yatu Departemen perwakafan/Agama, lembaga wakaf dan perusahaan pengelola. Pendekatannya adalah ibadah, baru bisnis. Sistem ini telah berjalan dengan baik di kuwait. Melalui sistem wakaf investasi inilah mereka dapat membiaya berbagai kegiatan umat dan lembaga Islam di berbagai negara.

\section{Peranan Wakaf dalam Mengatasi Kemiskinan dan Ketergantungan}

Optimalisasi dalam pengelolaan lembagalembaga ekonomi Islam terutama wakaf di Indonesia harus segera dilakukan, sehingga peningkatan perekonomian umat dapat segera terwujud sebagaimana yang diharapkan, benda-benda wakaf yang tidak jelas status hukumnya dan tidak terurus secara baik perlu diatasi agar produktif dan bermanfaat. Apabila wakaf dikembangkan secara benar, maka akan memiliki nilai yang sangat strategis untuk meningkatkan perekonomian ummat dan lambat laun akan mengurangi kesenjangan antara kaum aghnia' dan kaum dlu'afa.

Disahkannya Undang-undang No 41 Tahun 2004 tentang Wakaf merupakan bukti adanya kesepakatan dan keinginan kuat bagi umat Islam untuk mengembangkan lembaga wakaf secara produktif. Disamping itu akan menjadi landasan hukum yang kuat untuk mengembangkan wakaf secara produktif, khususnya wakaf tunai.

Dalam Penjelasan Undang-undang
Nomor 41 Tahun 2004 Tentang Wakaf tersebut dikemukakan bahwa salah satu langkah strategis untuk meningkatkan kesejahteraan umum, perlu meningkatkan peran wakaf sebagai pranata keagamaan yang tidak hanya bertujuan menyediakan berbagai sarana ibadah dan sosial, tetapi juga memiliki kekuatan ekonomi yang berpotensi antara lain untuk memajukan kesejahteraan umum sehingga perlu dikembangkan pemanfaatannya sesuai dengan prinsip syariah. Dalam UndangUndang Tentang Wakaf itu juga sudah diatur berbagai hal yang penting dalam pengembangan wakaf produktif. Sebagai contoh misalnya benda wakaf yang diatur dalam UndangUndang itu tidak hanya dibatasi pada benda tidak bergerak tetapi juga benda bergerak seperti uang, logam mulia, surat berharga, kendaraan, hak atas kekayaan intelektual, hak sewa dan benda bergerak lain sesuai dengan ketentuan syari'ah dan petaturan perundangundangan yang berlaku.

Dalam Undang-Undang Tentang Wakaf, wakaf uang juga diatur dalam bagian tersendiri. Dalam Pasal 28 Undang-undang tersebut disebutkan bahwa wakif dapat mewakafkan benda bergerak berupa uang melalui lembaga keuangan syariah yang ditunjuk oleh Menteri. Kemudian dalam Pasal 29 ayat (1) disebutkan pula bahwa wakaf benda bergerak berupa uang sebagaimana dimaksud dalam Pasal 28, dilaksanakan oleh wakif dengan pernyataan kehendak yang dilakukan secara tertulis, ayat (2) Pasal yang sama dinyatakan bahwa wakaf benda bergerak berupa uang sebagaimana dimaksud dalam ayat (1) diterbitkan dalam bentuk sertifikat wakaf uang. Dalam ayat (3) Pasal yang sama diatur bahwa sertifikat wakaf uang sebagaimana dimaksud dalam ayat (2) 
diterbitkan dan disampaikan oleh lembaga keuangan syari'ah kepada wakif dan nadzir sebagai bukti penyerahan harta benda wakaf. Kemudian dalam pasal 31 dinyatakan bahwa ketentuan mengenai wakaf benda bergerak yang berupa uang sebagaimana dimaksud dalam Pasal 28, Pasal 29 dan Pasal 30 diatur lebih lanjut dengan Peraturan Pemerintah.

Objek wakaf seharusnya dikelola secara baik sesuai dengan tujuan wakif mewakafkannya. Wakif selalu berharap agar amal sholeh selalu didapatkan darinya. Namun terbukti pengelolaan wakaf ini memang tidak mudah, karena dalam pengelolaannya harus melalui berbagai usaha, dan usaha ini mempunyai risiko yang cukup tinggi. Oleh karena itu pengelolaan yang mampu melahirkan amal sholeh dan pengembangan benda wakaf, khususnya wakaf uang harus dilakukan oleh Nadzir yang profesional. Adapun syarat-syarat yang dibutuhkan untuk menjadi Nadzir yang idial dan profesional adalah:

1. Beriman, amanah, memiliki kridibilitas di masyarakat dan tidak terhalang melakukan perbuatan hukum

2. Memahami hukum wakaf dan peraturan perundang-undangan yang terkait dengan masalah perwakafan, serta prakik-prektik perwakafan khususnya wakaf uang di berbagai negara. Dengan demikian Nazhir mampu untuk mertindak secara kreatif, inovatif dalam pengembangan wakaf dan benar setiap mengatasi permasalahan

3. Memiliki dan memahami pengetahuan mengenai ekonomi syari'ah dan instrument keuangan syari'ah. Sebab wakaf adalah salah satu lembaga ekonomi Islam yang sangat potensial untuk dikembangkan.

4. Memiliki kemampuan untuk mengumpulkan dana wakaf yang cukup besar dan dapat mengelola keuangan secara professional dengan menggunakan prinsip-prinsip syariah, transparansi dan akuntabel. seperti melakukan investasi dana wakaf dan mendistribusikan hasil investasi dana wakaf kepada mauquf 'alaihi.

Dengan syarat-syarat yang demikian, diharapkan nadzir benar-benar dapat mengembangkan wakaf dengan baik, dan masyarakat dapat dan tidak enggan untuk memantaunya. Dengan demikian hasil investasi wakaf tersebut dapat dipergunakan untuk mengembangkan ekonomi ummat, mengatasi kemiskinan dan ketergantungan..

Dalam rangka pengelolaan dan pengembangan wakaf inilah perlunya pembibitan dan pembinaan Nazhir agar profesional dan amanah dalam mengemban tanggungjawab. Untuk itu di dalam Undang-undang 41 Tahun 2004 Tentang Wakaf Bab VI pasal $47 \mathrm{~s} / \mathrm{d}$ pasal 49 diamanatkan perlunya dibentuk Badan Wakaf Indonesia. Salah satu tugas dan wewenang Badan Wakaf Indonesia adalah melakukan pembinaan terhadap nazhir dalam mengelola dan mengembangkan harta benda wakaf.

Tujuan dibentuk Badan Wakaf Indonesia antara lain untuk memajukan dan mengembangkan perwakafan nasional. Dalam melaksanakan tugasnya Badan Wakaf Indonesia (BWI) bersifat independen. Dalam UU tentang Wakaf Pasal 48 disebutkan bahwa Badan Wakaf Indonesia berkedudukan di ibukota Negara Kesatuan Republik Indonesia dan dapat membentuk perwakilan di propinsi dan atau kabupaten/kota sesuai dengan kebutuhan. Dalam Pasal 49 ayat (1) disebutkan Badan Wakaf Indonesia mempunyai tugas dan wewenang:

a. melakukan pembinaan terhadap nazhir 
dalam mengelola dan mengembangkan harta benda wakaf;

b. melakukan pengelolaan dan pengembangan harta benda wakaf berskala nasional dan internasional;

c. memberikan persetujuan dan atau izin atas perubahan peruntukan dan status harta benda wakaf;

d. memberhentikan dan mengganti nazhir;

e. memberikan persetujuan atas penukaran harta benda wakaf;

f. memberikan saran dan pertimbangan kepada Pemerintah dalam penyusunan kebijakan di bidang perwakafan.

Dalam Pasal yang sama ayat (2) disebutkan bahwa dalam melaksanakan tugasnya Badan Wakaf Indonesia dapat bekerjasama dengan instansi Pemerintah baik Pusat maupun Daerah, organisasi masyarakat, para ahli, badan internasional, dan pihak lain yang dianggap perlu.

Memperhatikan kedudukan, tugas dan wewenang Badan Wakaf dalam UndangUndang tersebut, nampak bahwa tanggungjawab Badan Wakaf sangat besar dalam rangka memajukan dan mengem-bangkan perwakafan nasional, sehingga fungsi obyek wakaf dapat dirasakan oleh seluruh ummat khususnya para wakif seperti yang disyariatkan. Untuk itu penempatan orang untuk duduk di Badan Wakaf harus selektif professional dan amanah sesuai yang dibutuhkan oleh badan itu sendiri.... Satu hal yang penting dalam UU ini adalah masalah peruntukan wakaf. Dalam Penjelasan Umum UU ini disebutkan bahwa peruntukan benda wakaf tidak semata-mata untuk kepentingan sarana ibadah dan sosial tetapi juga diarahkan untuk memajukan kesejahteraan umum dengan cara mewujudkan potensi dan manfaat ekonomi harta benda wakaf. Hal itu memungkinkan pengelolaan harta benda wakaf dapat memasuki wilayah kegiatan ekonomi dalam arti luas sepanjang pengelolaan tersebut sesuai dengan prinsip manajemen dan ekonomi syari'ah.

Pengembangan wakaf tunai secara produktif sudah dilakukan di berbagai Negara seperti Turki, Bangladesh, Sudan, Kuwait, dan lain-lain. Beberapa tahun yang lalu, Kementerian Wakaf Kuwait melakukan penertiban semua manajemen wakaf yang ada dalam satu lembaga wakaf. Dalam melaksanakan tugasnya, lembaga wakaf ini menggunakan sistem kerja terstruktur berdasarkan bidang dan spesialisasi masing-masing, namun tetap untuk mencapai tujuan yang sama dalam memanaj semua harta wakaf. Maka untuk merealisasikan tujuan dari pembentukan lembaga wakaf ini, dibentuk dua bagian utama, yaitu:

1. Bagian investasi dan pengembangan harta wakaf lama dan baru dan pencapaian hasilhasilnya.

2. Bagian penyaluran hasil-hasil wakaf yang ada sesuai dengan tujuannya masing-masing dan melakukan kampanye pembentukan wakaf baru yang dapat memberi pelayanan kepada masyarakat berdasarkan prioritas dan tingkat kebutuhannya.

Sistem kerja terstruktur tersebut telah membentuk dua bagian penting dalam lembaga wakaf, yaitu bagian investasi yang terdiri dari beberapa bagian, misalnya bagian investasi bidang properti dan non properti, bagian dana dan proyek yang terdiri dari beberapa saluran dana dan proyek yang diperlukan dalam masyarakat. Bagian investasi dalam lembaga wakaf ini secara khusus menangani investasi harta wakaf dan mengembangkannya, serta mengoptimalkan pelaksanaannya untuk meningkatkan hasilhasilnya. Strategi investasi pada bagian investasi bersandar pada sistem terstruktur 
yang melaksanakan tugasnya sesuai dengan spesialisasi dan bidangnya masing-masing. Bidang investasi properti dan non properti seperti keuangan, jasa dan lain-lain; masingmasing mempunyai kantor sendiri, tetapi semua bagian nenjalin kerjasama antara satu dengan lainnya dalam rangka menjaga kelancaran dan pelaksanaan investasi ideal yang meliputi semua jenis investasi dengan resiko yang kecil, dan secara geografis kawasan investasi mudah melakukan distribusi. Lembaga wakaf di Kuwait ini telah memberi kontribusi yang sangat besar dalam membuat berbagai kawasan investasi keuangan yang semuanya terikat dengan hukum syari'ah, dan telah diagendakan untuk jangka pendek, menengan dan jangka panjang.

Selain di Kuwait, wakaf dalam bentuk investasi ini juga sudah dikembangkan di Turki. Pada saat ini di Turki sudah didirikan Waqf Bank \& Finance Corporation untuk memobilisasi sumber-sumber wakaf dan untuk membiayai bermacam-macam jenis proyek joint venture. Wakaf di Turki di kelola oleh Direktorat Jendral Wakaf dan Mutawalli. Direktorat Jendral ditunjuk oleh Perdana Menteri dan dibawah Kantor Perdana Menteri. Direktorat Jendral wakaf disamping mengekiola wakaf juga bertugas melakukan supervisi dan kontrol terhadap wakaf yang dikelola oleh mutawalli maupun wakaf yang baru (Art 78 Civil Law) dan melakukan kerjasama dan investasi di berbagai lembaga, antara lain: Auqaf Guraba Hospital; Taksim Hotel (Sheraton); Turkish Is Bank; Aydin Textile Industry; Import Corporation.
Menurut M.A. Mannan, wakaf tunai dapat berperan sebagai suplemen bagi pendanaan berbagai macam proyek investasi sosial yang dikelola oleh bank-bank islam, sehingga dapat berubah menjadi bank wakaf (sebuah bank yang menampung dana-dana wakaf). Di Bangladesh wakaf tunai memiliki arti yang sangat penting dalam memobilisasi dana bagi pengembangan wakaf properti. Social Investment Bank Ltd (SIBL) mengintrodusir Sertifikat Wakaf Tunai, suatu produk baru dalam sejarah perbankan sector voluntary. Di Dhaka, Bangladesh SIBL mernbuka peluang kepada masyarakat untuk membuka rekening deposito wakaf tunai dengan tujuan mencapai sasaransasaran berikut: (1) Menjadikan perbankan sebagai fasilitator untuk menciptakan wakaf tunai dan membantu dalam pengelolaan wakaf; (2) Membantu memobilisasi tabungan masyarakat; (3) Meningkatkan investasi sosial dan mentransformasikan tabungan masyarakat menjadi modal; (4) Memberikan manfaat kepada masyarakat luas terutama golongan miskin, dengan menggunakan sumber-sumber yang diambilnya dari golongan orang kaya; (5) Menciptakan kesadaran di antara orang kaya tentang tanggungjawab sosial mereka terhadap masyarakat; (6) Membantu pengembangan Social Capital Market, (7) Membantu usaha-usaha pembangunan bangsa secara umum dan membuat hubungan yang unik antara jaminan sosial dan kesejahteraan masyarakat ${ }^{14}$.

Adapun sasaran pemanfaatan dana hasil pengelolaan wakaf tunai yang dikelola oleh SIBL antara lain adalah untuk: peningkatan standar hidup orang miskin; rehabilitasi orang cacat; peningkatan standar hidup penduduk

${ }_{14}$ M.A. Mannan, Cash-Waqf Certificate Global Opportunities for Developing the Social Capital Market in 21 Century Voluntary Sector Banking, Cambridge, Harvard, University, 1999, HIm 249-250. 
hunian kumuh; membantu pendidikan anak yatim piatu; beasiswa; pengembangan pendidikan moderen; pengembangan sekolah, madrasah, kursus, akademi dan universitas; mendanai riset; membantu pendidikan keperawatan; riset penyakit tertentu dan membangun pusat riset; mendirikan rumah sakit dan bank darah; membantu program riset, pengembangan, dan pendidikan untuk menghormati jasa para pendahulu; menyelesaikan masalah-masalah sosial non muslim; membantu proyek-proyek untuk penciptaan lapangan kerja yang penting untuk untuk menghapus kemiskinan sesuai dengan syari'at Islam, dan lain-lain ${ }^{15}$.

\section{Simpulan}

Pengembangan lembaga-lembaga ekonomi dalam Islam seperti zakat, infaq, shadaqah, wakaf dan lembaga-lembaga Islam lain seperti perbangkan Islam, asuransi syariah, reksadana syariah dan lain-lain, dalam rangka meningkatkan ekonomi umat dan untuk mengatasi kemiskinan dan ketergantungan, dapat dilakukan dengan menggunakan manajemen modern dan dikelola oleh orangorang yang profesional, amanah, produktif serta selalu mendasarkan pada ajaran Islam dan peraturan perundang-undangan yang terkait. Dalam pengelolaan lembaga ekonomi Islam tersebut masing-masing harus berkait satu dengan yang lain dan memiliki sinergi tinggi seperti bangunan yang kokok saling memperkokoh (kal-bunyanun marsus yasuddu ba'duhum ba'da). Komitmen umat Islam khususnya 'ulama, intelektual muslim sangat dibutuhkan dalam rangka pengembangan ekonomi ummat khususnya wakaf produktif, karena komitmen itu sendiri merupakan modal awal dari perjalanan untuk menuju peningkatan kesejahteraan ummat yang terhindar dari kemiskinan dan ketergantungan. Kita tidak boleh membiarkan kita, saudara kita, bangsa kita dalam kondisi serba lemah, tertinggal, dan selalu bergantung dengan negara-negara lain, tetapi kita harus selalu menolong kita, saudara kita, bangsa kita menjadi kuat dan mampu membantu bangsa lain yang lemah. Wallahu a'lam bis-shoab.

\section{Daftar Pustaka}

Abdul Wahhab Khallaf, Ahkam.al-Waaf. Mesir: Mathba'ah al-Misr, 1951.

Ahmad Azhar Basyir, Hukum Islam tentang Wakaf, Jjarah dan Syirkah, Bandung, AlMa'arif, 1987

Ahmad, Khurshid (ed.), Pesan Islam, diterjemahkan oleh Achsin Muhammad, Bandung: Pustaka, 1983.

Ahmad M Saifuddin, Studi Nilai-nilai Sistem Ekonomi Islam (Jakarta: Media Dakwah, 1984.

Departemen Agama, Kompilasi Hukum Islam Indonesia, Direktorat Pembinaan Badan Peradilan Agama, 1992).

Jumhuriyyah Misr al-'Arabiyyah, Qawanin alAuqafwa al-Hikr wa Qararat alTanfiziyyah, Cayro:Al-Haiah al-vAmmah li Syuun al-Matabi al-Amiriyyah, 1993. Mohammad Najatullah Siddqi, The Economi Enterprises In Islam, Isiamic Publication LTD, Pakistan

M.A. Mannan, Cash-Wagf Certificate Global Opportunities for Developing the Social

${ }^{15}$ lbid., HIm.253 
Capital Market in 21 Century Voluntary Sector Banking, Cambridge, Harvard, University, 1999

Mohammad Daud Ali, Sistem Ekonomi Islam, Zakat dan Wakaf, Jakarta: UI Press, 1988. Mundzir Kahaf, Managemen Wakaf Produktif. diterjemahkan oleh Muhyiddin Mas Rida, Jakarta: Khalifa (Pustaka alKautsar Grup), 2005.

Rachmad Djatniko, Pandangan Islam tentang Infak, Sadaqah, Zakat dan Wakaf Sebagai Kompenen dalam Pembangunan, Al-
Ikhlas, Surabaya. 1984

Saayid Sabiq, Fikih Sunnah jild 14, diterijemahkan oleh Drs.H. Kahaar Mashur, Jakarta, Kalam Mulia, 1991

Sutarmadi, Muhda Hadisaputra dan Amidhan, Pedoman Praktis Perwakafan, (Jakarta: Badan Kesejahteraan Masjid, 1990).

Soeprapto, "Perubahan Peruntukan/Penggunaan Tanah Wakaf dari SudutAgrania', mimeo, Makalah disampaikan Temu Wicara Perwakafan Tanah Milik, Departemen Agara Rl, Jakarta, 1987. 